\title{
PENERAPAN MODEL PBL BERBANTUAN E-MODUL BERBASIS FLIPBOOK DIBANDINGKAN BERBANTUAN BAHAN AJAR CETAK PENGARUHNYA TERHADAP HASIL BELAJAR PEMROGRAMAN SISWA SMK
}

\author{
Alipah Nurhidayati \\ Setiadi Cahyono Putro \\ Triyanna Widiyaningtyas
}

\begin{abstract}
Abstrak: Tujuan penelitian ini untuk mendiskripsikan peningkatan hasil belajar pemrograman karena pengaruh penerapan PBL berbantu e-modul, mendiskripsikan peningkatan hasil belajar pemrograman karena pengaruh penerapan PBL berbantu bahan ajar cetak, dan mengungkap perbedaan rerata hasil belajar pemrograman karena pengaruh PBL berbantu $e$-modul dibandingkan PBL berbantu bahan ajar cetak. Subjek penelitian ini yaitu siswa kelas X TKJ 1 dan X TKJ 2 di SMKN 7 Malang yang masing-masing berjumlah 25 siswa. Hasil penelitian menunjukkan bahwa terdapat peningkatan hasil belajar karena penerapan model PBL dengan berbantuan e-modul sebesar 0.47, peningkatan hasil belajar karena penerapan model PBL dengan berbantuan bahan ajar cetak sebesar 0.24 , dan perbedaan hasil belajar ranah pengetahuan dengan sig $0.001<0.05$. Kesimpulan dari penelitian terdapat peningkatan serta perbedaan hasil belajar pemrograman dasar siswa pada kelas bahan ajar e-modul dan dengan kelas bahan ajar cetak.
\end{abstract}

Kata-kata Kunci: problem based learning, hasil belajar, e-modul, bahan ajar cetak

Abstract: The Effect of the Application of PBL Models using Flipbook-Based EModul and Printed-Based Materials on Student Learning Results in Programming Course at Vocational High School. This research aims to describe the improvement of the learning outcomes of the program because of the influence of the application of e-module-assisted PBL, to describe the increase in programming learning outcomes because the effect of implementing PBL was helped by print teaching, and to reveal the average differences in learning outcomes in the programming of the influence of e-module-assisted PBL compared to PBL with printed teaching materials. The subjects of this study were students of class X TKJ 1 and X TKJ 2 at SMKN 7 Malang, each of which consisted of 25 students. The results showed that there were an increase in the learning result because of the application of PBL learning model with the use of an e-module by 0.47, improvement of learning outcomes because of the application of PBL learning models with the use of printed materials is as much as 0.24 , and significant differences in learning outcomes of cognitive aspect with sig $0.001<0.05$. The study concludes that there is an increase and a difference in the student learning outcome in basic programming course between e-module material classes and printed material classes.

Keywords: problem based learning, learning result, e-modul and printed materials

$\mathrm{M}$ utu pendidikan masih saja menjadi masalah dalam dunia pendidikan di Indonesia. Masalah mutu pendi- dikan yang masih banyak ditemui adalah tentang rendahnya hasil belajar peserta didik. Berdasarkan observasi yang dila-

Alipah Nurhidayati adalah Mahasiswa Jurusan Teknik Elektro Universitas Negeri Malang. Alamat Kampus: Jl. Semarang No. 5 Malang 65145. Email: alifahnurhidayati@gmail.com. Setiadi Cahyono Putro dan Triyanna Widiyaningtyas adalah Dosen Jurusan Teknik Elektro Universitas Negeri Malang. Alamat Kampus: Jl. Semarang No. 5 Malang 65145. 
kukan di SMKN 7 Malang diketahui bahwa hasil belajar pemrograman dasar siswa masih rendah. Hal ini dapat dilihat dari banyaknya siswa yang memperoleh nilai di bawah Kriteria Ketuntasan Minimal (KKM 80) sebesar 77,00\%. Berdasarkan observasi, bahan ajar yang digunakan dalam pemrograman dasar ini dirancang oleh guru dan dikemas dalam format PDF. Dalam proses pembelajarannya siswa hanya diberikan file pdf dan terkadang diperintahkan untuk mencetaknya, agar lebih mudah membaca bahan ajar tersebut. Namun bahan ajar seperti itu membuat siswa cenderung pasif karna terlalu banyak sajian materi berbentuk teks dan tidak ada ilustrasi yang memicu di dalamnya. Dengan demikian, pembelajaran menjadi kurang optimal karena cenderung menimbulkan kebosanan dan berimbas pada hasil belajar siswa.

Mata pelajaran pemrograman dasar merupakan mata pelajaran yang menuntut siswa untuk belajar mendeskripsikan dan merancang sistematika pemecahan masalah menggunakan statement dalam bahasa yang dimengerti oleh komputer. Dalam merancang sistematika pemecahan masalah tentu siswa akan merasa kesulitan karena harus benar-benar memahami setiap statement yang akan digunakan. Dengan demikian, penggunaan bahan ajar yang menarik diharapkan mampu untuk menciptakan mi-nat baru peserta didik dalam memrogram.

Selain penggunaan bahan ajar yang menarik, model pembelajaran juga diperlukan untuk dapat mencapai tujuan pembelajaran. Menurut Hosnan (2014: 337), model pembelajaran adalah kerangka konseptual yang berisikan prosedur yang tersusun secara sistematis untuk membangun pengalaman belajar dalam mencapai tujuan belajar. Sedangkan menurut Rusman (2010:57) model pembelajaran merupakan rancangan pembelajaran yang terkonsep secara sistematis dari awal hingga akhir pembelajaran yang disajikan secara khusus oleh guru. Berdasarkan observasi, sebenarnya guru pada mata pelajaran pemrograman dasar sudah menggunakan model pembelajaran, namun pada penerapannya kurang terlaksana dengan baik.

Penggunaan dan pemilihan model pembelajaran, seorang guru harus memperhatikan karakteristik dari siswa dan mata pelajarannya. Dalam hal ini, model pembelajaran Problem Based Learning dirasa cocok untuk diterapkan pada mata pelajaran pemrograman dasar di kelas $\mathrm{X}$ TKJ SMKN7 Malang.

Ramadhan, dkk (2016:723) mengemukakan bahwa PBL merupakan sebuah pola belajar yang berpusat pada proses penyelesaian masalah, siswa akan dihadapkan pada sebuah permasalahan oleh guru yang kemudian diperintahkan untuk mengidentifikasi dan mencari solusi dari permasalahan tersebut.

Karakteristik dari model Problem Based Learning menurut Rusman (2010: 232) adalah: (1) permasalahan menjadi puncak dalam belajar; (2) permasalahan yang diambil merupakan permasalahan pada dunia nyata; (3) permasalahan membutuhkan sudut pandang yang berbeda; (4) permasalahan menantang pengetahuan siswa, sikap, dan kompetensi belajar; (5) belajar untuk mengarahkan diri menjadi hal yang penting; (6) pemanfaatan sumber pengetahuan yang bermacam-macam dan evaluasi sumber informasi merupakan proses yang fundamental dalam model ini; (7) belajar adalah kolaboratif, komunikasi, dan kooperatif; (8) pengembangan keterampilan inquiry dan pemecahan masalah memiliki kedudukan yang sama pentingnya dengan penguasaan materi dalam menyelesaikan permasalahan; (9) sintesis dan integrasi dari sebuah proses belajar; dan (10) problem based learning melibatkan evaluasi dan review pengalaman belajar siswa dari serangkaian proses pembelajaran. 
Pelaksanaan PBL selama proses pembelajaran memiliki kelebihan, menurut Warsono dan Hariyanto (2012:152) kelebihan PBL tersebut antara lain: (1) siswa akan terbiasa menantang masalah baik dalam pembelajaran di kelas maupun dalam kehidupan sehari-hari; (2) menumbuhkan solidaritas sosial dengan terbiasa berdiskusi dengan teman-teman; (3) guru akan semakin dekat dengan siswa; dan (4) membiasakan siswa melakukan penelitian.

Penggunaan model pembelajaran yang tepat pada dasarnya bertujuan untuk menciptakan kondisi pembelajaran yang memungkinkan siswa dapat belajar secara aktif untuk memicu perolehan hasil belajar dan prestasi yang optimal. Hasil belajar menurut Nawawi (dalam Susanto, 2013:5) merupakan tingkat keberhasilan siswa dalam memahami materi pelajaran di akhir proses pembelajaran. Penelitian ini dilakukan untuk mengeksperimen dalam menentukan bahan ajar yang sesuai untuk digunakan dan diterapkan dalam proses belajar mengajar, dengan menerapkan model Problem Based Learning berbantuan e-modul berbasis flipbook dibandingkan berbantuan bahan ajar cetak pengaruhnya terhadap hasil belajar pemrograman dasar pada siswa kelas X TKJ di SMK Negeri 7 Malang. Tujuan penelitian: (1) mendiskripsikan peningkatan hasil belajar pemrograman karena pengaruh penerapan PBL berbantu e-modul, (2) mendiskripsikan peningkatan hasil belajar pemrograman karena pengaruh penerapan PBL berbantu bahan ajar cetak, dan (3) mengungkap perbedaan rerata hasil belajar pemrograman karena pengaruh PBL berbantu e-modul dibandingkan PBL berbantu bahan ajar cetak.

\section{METODE}

Desain eksperimen yang digunakan dalam penelitian adalah eksperimen semu (quasi eksperimental) karena tidak semua gejala yang timbul dapat di eksperimen maupun di kontrol. Penelitian eksperimen semu digunakan untuk mengetahui perbedaan kemampuan kelas yang diberi perlakuan dan kelas yang tidak diberi perlakuan. Rancangan penelitian yang digunakan adalah Posttest Only, Non-Equivalent Control Group Desain. Dalam penelitian ini akan terdapat dua kelompok yang tidak dipilih secara random. Rancangan penelitian dapat dilihat pada Tabel 1.

Penelitian ini menggunakan tiga variabel penelitian yaitu, variabel bebas, terikat, dan kontrol. Terdapat dua variabel bebas yaitu, bahan ajar e-modul dan bahan ajar cetak. Kedua variabel ini dipilih karena yang menyebabkan terjadinya perubahan pada va-riabel terikat. Variabel terikat pada penelitian ini yaitu hasil belajar pemrograman dasar siswa. Variabel kontrol disebut pula sebagai variabel kendali.

Adapun variabel yang dikontrol yaitu: (1) guru. Guru yang mengajar di kedua kelas haruslah sama; (2) waktu. Waktu pembelajaran di kedua kelas haruslah beriringan; (3) materi. Materi yang diajarkan di kedua kelas haruslah sama; dan (4) kondisi lingkungan. Kondisi lingkungan kelas dari kedua kelas eksperimen haruslah sama stretegisnya.

Subjek penelitian adalah siswa kelas $X$ TKJ 1 dan X TKJ 2 di SMKN 7 Malang yang masing-masing berjumlah 25 siswa. Penelitian dilaksanakan di SMKN

Tabel 1. Rancangan Penelitian

\begin{tabular}{cc}
\hline \multicolumn{2}{c}{ Model } \\
\hline PBL $+\mathrm{A}_{1}$ & PBL $+\mathrm{A}_{2}$ \\
\hline H.Kog & H.Kog \\
\hline
\end{tabular}

Keterangan:

Model : Model Pembelajaran PBL (Project Based Learning)

$\mathrm{PBL}+\mathrm{A}_{1}$ : Model Pembelajaran PBL berbantuan bahan ajar e-modul

$\mathrm{PBL}+\mathrm{A}_{2}$ : Model Pembelajaran PBL berbantuan bahan ajar cetak

H.Kog : Hasil Belajar Kognitif(Pengetahuan) 
7 Malang dengan waktu penelitian yaitu semester genap tahun ajaran 2017/2018.

Arikunto (2010:203) mengemukakan bahwa instrumen penelitian merupakan suatu piranti yang digunakan oleh peneliti dalam mengumpulkan data untuk mempermudah pekerjaannya, sehingga dapat mengolah datanya dengan baik dan benar. Instrumen penelitian yang digunakan adalah instrumen perlakuan dan instrumen pengukuran.

Instrumen perlakuan berupa silabus, RPP, dan materi pembelajaran. Instrumen pengukuran berupa tes kemampuan awal (pre-test) dan tes kemampuan akhir (posttest). Tetapi pada penelitian ini tidak dilakukan pre-test, dikarenakan data awal yang akan digunakan dapat diambil dari hasil akhir semester ganjil pemrograman dasar yang telah diberikan oleh guru sebelumnya. Sedangkan pada tes kemampuan akhir, siswa akan diberikan soal posttest.

Soal posttest dibuat dalam beberapa tahap. Tahap pembuatan soal posttest meliputi: (1) melakukan observasi awal di sekolah yang ingin diteliti; (2) menetapkan kelas eksperimen dan kelas kontrol; (3) menyusun perangkat pembelajaran dalam penelitian; (5) melakukan uji coba instrumen tes; dan (6) revisi instrumen tes apabila diperlukan.

Sebelum digunakan untuk pengumpulan data, instrumen penelitian yang telah dibuat harus diuji coba terlebih dahulu. Uji coba instrumen penelitian meliputi uji validasi ins-trumen perlakuan dan uji validasi instrumen pengukuran. Instrumen perlakuan yang akan divalidasi adalah RPP. Validasi RPP digunakan untuk mengetahui kelayakan RPP dalam proses pembelajaran yang akan dilakukan. RPP tersebut divalidasi oleh guru mata pelajaran pemrograman dasar di SMKN 7 Malang dengan persentase
90,00\% dan dosen akademik Teknik Elektro UM sebesar 95,00\%. Sehingga, instrumen RPP memiliki validitas sangat tinggi karena rata-rata persentase sebesar $93,00 \%$.

Instrumen pengukuran yang akan di validasi adalah soal posttest dan butir soal. Validasi soal posttest digunakan untuk mengetahui kelayakan pemakaian soal tes dalam proses pembelajaran yang akan dilakukan. Soal instrumen tersebut divalidasi oleh guru mata pelajaran pemrograman dasar di SMKN 7 Malang sebesar 95,00\% dan dosen akademik Teknik Elektro UM sebesar 90\%. Sehingga, instrumen soal tes memiliki validitas sangat tinggi karena rata-rata persentase sebesar 93,00\%.

Menurut Rusdiharti (2017:51) sebuah item dikatakan valid jika memiliki dukungan yang besar terhadap skor total. Pada penelitian ini, validitas butir soal yang digunakan adalah untuk mengetahui kesahihan pada setiap butir soal yang membedakan antara siswa berkemampuan tinggi dan siswa berkemampuan rendah. Validitas butir soal dihitung dengan rumus Product Moment menggunakan IBM SPSS Statistic 23. Butir soal dinyatakan valid jika nilai signifikansi kurang dari 0.05; dan (3) reliabilitas. Pengujian reliabilitas dilakukan dengan menggunakan metode perhitungan Alpha Cronbach's 0 sampai 1.

Teknik analisis data yang digunakan meliputi analisis deskriptif, uji prasyarat analisis, uji kesamaan rata-rata kemampuan awal siswa dan uji hipotesis. Analisis deskriptif digunakan untuk pemberian skor yang dikategorikan pada masingmasing tingkatan. Uji prasyarat analisis digunakan untuk mengolah data awal siswa dan data akhir siswa sebelum data diuji hipotesisnya. 
Uji prasyarat analisis merupakan uji statistik yang terdiri dari uji normalitas dan uji homogenitas. Uji normalitas pada penelitian ini menggunakan uji One Sample Kolmogrov Smirnov yaitu untuk mengetahui apakah data hasil belajar pada dua kelompok siswa berdistribusi normal atau tidak. Uji homogenitas varians dalam penelitian ini menggunakan uji Levene's yaitu pengujian untuk kesamaan varian.

Uji kesamaan rata-rata kemampuan awal siswa digunakan untuk mengevaluasi perbedaan rata-rata kemampuan awal siswa pada kelas e-modul dan kelas bahan ajar cetak. Rumus yang akan digunakan adalah Independent Sample t-test. Hasil uji kesamaan rata-rata kemampuan awal siswa diperoleh nilai signifikansi sebesar 0.367. Nilai 0.367 lebih besar dari 0.05 , sehingga dapat diindikasikan bahwa tidak ada perbedaan rata-rata hasil belajar pada kelas e-modul dan kelas bahan ajar cetak.

Uji hipotesis dilakukan untuk menguji ada tidaknya perbedaan yang signifikan dari hasil belajar pemrograman dasar setelah diberi perlakuan. Uji hipotesis pada penelitian menggunakan uji-t. Peningkatan hasil belajar pemrograman dasar siswa pada kelas e-modul dan kelas bahan ajar cetak dapat dihitung dari nilai perolehan gain score. Gain Score adalah selisih antara nilai pretest dan nilai posttest dari siswa pada kelas e-modul dan kelas bahan ajar cetak.

\section{HASIL}

Hasil belajar yang dianalisis dalam penelitian ini yaitu hasil belajar pada ranah kognitif. Hasil belajar dianalisis berdasarkan jawaban siswa dalam soal posttest yang diberikan. Soal posttest tersebut merupakan soal uraian berjumlah 10 butir. Distribusi frekuensi data nilai pre-post kelas e-modul dapat dilihat pada Tabel 2. Distribusi frekuensi data nilai pre-post kelas bahan ajar cetak dapat dilihat pada Tabel 3.

Berdasarkan Tabel 2, rata-rata pretest siswa yang didapatkan dari kelas

Tabel 2. Distribusi Frekuensi Data Nilai Pre-Post Kelas E-Modul

\begin{tabular}{lrr}
\hline & Pretest & Posttest \\
\hline Mean & 74.920 & 86.800 \\
Median & 75.000 & 88.000 \\
Mode & $72.00^{\mathrm{a}}$ & $92.00^{\mathrm{a}}$ \\
Std. Deviation & 3.06757 & 6.05530 \\
Range & 14.00 & 22.00 \\
Minimum & 70.00 & 71.00 \\
Maximum & 84.00 & 93.00 \\
\hline Sum & 1873.00 & 2170.00 \\
\hline Ketuntasan & $32 \%$ & $96 \%$ \\
\hline Peningkatan & \multicolumn{2}{c}{$68 \%$} \\
Ketuntasan & \multicolumn{2}{c}{} \\
\hline
\end{tabular}

Tabel 3. Distribusi Frekuensi Data Nilai Pre-Post Kelas Bahan Ajar Cetak

\begin{tabular}{lrr}
\hline & Pretest & Posttest \\
\hline Mean & 73.960 & 80.080 \\
Median & 74.000 & 82.000 \\
Mode & 74.00 & $82.00^{\mathrm{a}}$ \\
Std. Deviation & 4.28641 & 7.02922 \\
Range & 22.00 & 29.00 \\
Minimum & 60.00 & 60.00 \\
Maximum & 82.00 & 89.00 \\
\hline Sum & 1849.00 & 2002.00 \\
\hline Ketuntasan & $28 \%$ \\
\hline Peningkatan & \multicolumn{2}{c}{$68 \%$} \\
Ketuntasan & \multicolumn{2}{c}{$60 \%$} \\
\hline
\end{tabular}

Tabel 4. Hasil Uji Prasyarat Analisis

\begin{tabular}{lcl}
\hline Kelas & .Sig & Keterangan \\
\hline E-Modul & 0.119 & $\begin{array}{l}\text { Berdistribusi } \\
\text { Normal }\end{array}$ \\
Bahan Ajar & 0.095 & $\begin{array}{l}\text { Berdistribusi } \\
\text { Normal }\end{array}$ \\
$\begin{array}{l}\text { E-tak } \\
\text { Bahad Ajar }\end{array}$ & 0.798 & $\begin{array}{l}\text { Homogen } \\
\text { Cetak }\end{array}$ \\
\hline
\end{tabular}

Tabel 5. Hasil Uji-t

\begin{tabular}{llll}
\hline Kelas & N & Mean & .Sig \\
\hline E-Modul & 25 & 86.80 & 0.001 \\
Bahan Ajar Cetak & 25 & 80.08 & 0.001 \\
\hline
\end{tabular}


e-modul sebesar 75. Sedangkan rata-rata posttest siswa dari kelas e-modul sebesar 87. Dari hasil ter-sebut diperoleh peningkatan ketuntasan belajar dari hasil belajar pemrograman dasar siswa yang dibelajarkan menggunakan model PBL berbantuan e-modul sebesar $68 \%$ dengan $\mathrm{N}$-Gain Score sebesar 11.88.

Berdasarkan Tabel 3, rata-rata pretest siswa yang didapatkan dari kelas bahan ajar cetak sebesar 74 . Sedangkan rata-rata posttest siswa dari kelas bahan ajar cetak sebesar 80. Dari hasil tersebut diperoleh peningkatan ketuntasan belajar dari hasil belajar pemrograman dasar siswa yang dibelajarkan menggunakan model PBL berbantuan bahan ajar cetak sebesar 60\% dengan $\mathrm{N}$-Gain Score sebesar 6.12 .

Berdasarkan hasil uji prasyarat analisis yang telah didapat, data hasil belajar pada kelas e-modul dan bahan ajar cetak berdistribusi normal. Dikatakan berdistribusi normal karena nilai signifikansi 0.119 dan 0.095 lebih besar dari 0.05. Kemudian data hasil belajar pada kelas emodul dan bahan ajar cetak dapat dinyatakan memiliki variansi yang identik (homogen). Dikatakan homogen karena nilai signifikansi 0.798 lebih besar dari 0.05. Hasil uji prasyarat analisis hasil belajar ranah kognitif siswa kelas e-modul dan kelas bahan ajar cetak dapat dilihat pada Tabel 4.

Setelah kedua data dapat dipastikan berditribusi normal dan homogen, maka selanjutnya dilakukan uji hipotesis terhadap kedua data tersebut. Hasil uji hipotesis kemampuan akhir siswa kelas e-modul dan kelas bahan ajar cetak dapat dilihat pada Tabel 5.

Hasil uji hipotesis kemampuan akhir siswa kelas e-modul dan kelas bahan ajar cetak memiliki signifikansi 0.001 . Nilai signifikansi 0.001 lebih kecil dari 0.05, sehingga $\mathrm{H}_{\mathrm{a}}$ diterima. Artinya, terdapat signifikansi perbedaan hasil belajar ranah pengetahuan pemrograman dasar karena pengaruh penerapan model PBL berbantuan e-modul dibandingkan berbantuan bahan ajar cetak.

\section{PEMBAHASAN}

Tujuan yang pertama dalam penelitian ini adalah mengungkapkan adakah peningkatan hasil belajar yang dipengaruhi oleh model pembelajaran PBL (Problem Based Learning) dengan menggunakan bahan ajar cetak. Menurut Rusdiharti (2017:25) bahan ajar merupakan bahan yang disusun secara sistematis oleh guru yang kemudian digunakan oleh peserta didik dalam proses pembelajaran. Bahan ajar yang disusun dalam buku ajar pendidik dapat berbentuk buku teks, modul, handout, LKS dan dapat juga dikemas dalam bentuk lainnnya.

Daryanto (2013:9) menyebutkan bahwa untuk menghasilkan modul yang mampu meningkatkan motivasi belajar, pengembangan suatu modul harus memperlihatkan karakterstik modul, yaitu: (1) self instructional. Maksud dari self instructional ini adalah seperangkat bahan ajar yang berbentuk cetak maupun online harus dapat bermanfaat dan digunakan oleh siswa secara mandiri; (2) self contained. Maksudnya ialah modul harus dapat memberikan kesempatan peserta didik untuk mempelajari materi pembelajaran dengan sempurna, karena materi pembelajaran dikemas ke dalam suatu bentuk yang utuh; (3) stand alone. Maksudnya ialah modul tidak harus dapat digunakan seiringan dengan bahan ajar lain atau media lain; (4) adaptif. Bahan ajar yang baik tidak hanya bisa berdiri sendiri, namun juga bisa mengikuti perkembangan teknologi; dan (5) user friendly. Bahan ajar yang sempurna seharusnya dapat memudahkan penggunaanya ketika hendak memakainya. 
Materi pembelajaran yang ada didalam bahan ajar cetak bersumber dari buku BSE yang beracuan pada silabus. Materi yang digunakan pada penelitian ini hanya berfokus pada KD 3.8 yaitu penggunaan array untuk menyimpan data di memori. Pada kelas bahan ajar cetak, sebelum diberikan perlakuan memiliki rata-rata hasil belajar ranah kognitif berkategori rendah. Sedangkan setelah diberi perlakuan, rata-rata hasil belajar ranah kognitif memiliki nilai berkategori tinggi. Dikatakan tinggi karena rata-rata hasil belajar siswa ranah kognitif sudah jauh di atas nilai KKM. Hal ini dikarenakan terdapat beberapa faktor yang mempengaruhi hasil belajar menggunakan bahan ajar cetak, yaitu: (1) terlalu banyak sajian materi berbentuk teks, sehingga cenderung menimbulkan kebosanan; (2) kurang dapat memberikan pemahaman bagi siswa; dan (3) cenderung digunakan sebagai alat bantu menghafal. Semua faktor tersebut dapat terlihat saat kelas diberikan perlakuan.

Tujuan kedua dalam penelitian ini adalah mengungkapkan adakah peningkatan hasil belajar yang dipengaruhi oleh model pembelajaran Problem Based Learning dengan menggunakan bahan ajar e-modul. Menurut Rachmawanto, dkk (2015:75) model pembelajaran PBL menggunakan masalah sebagai langkah awal dalam mengumpulkan dan mengembangkan pengetahuan baru yang didapatkan dari proses pembelajaran. Penerapan PBL ini dapat meningkatkan minat dan motivasi siswa sehingga tercipta siswa yang aktif dalam proses pembelajaran serta meningkatkan hasil belajar siswa.

Bahan ajar e-modul atau modul elektronik menurut Tim P2M LPPM UNS (dalam Rijal, 2014:17) adalah perangkat pembelajaran yang dirancang secara elektronik, berisi materi yang juga tersusun dengan sistematis dan menarik untuk mencapai tujuan pembelajaran.
Kelas yang menggunakan bahan ajar emodul adalah kelas eksperimen, yang mana model pembelajaran yang digunakan adalah PBL.

Pada kelas e-modul sebelum diberikan perlakuan memiliki rata-rata hasil belajar ranah kognitif berkategori rendah. Sedangkan setelah diberi perlakuan, ratarata hasil belajar ranah kognitif memiliki nilai berkategori sedang. Dikatakan sedang karena rata-rata hasil belajar siswa ranah kognitif berada sejajar dengan nilai KKM. Hal ini dikarenakan terdapat beberapa faktor yang mempengaruhi hasil belajar dengan menggunakan e-modul, yaitu: (1) mudah digunakan sebagai bahan ajar; (2) dapat menjadikan siswa belajar secara mandiri; dan (3) lebih memiliki inovasi didalamnya. Semua faktor tersebut dapat terlihat saat kelas diberikan perlakuan.

Tujuan ketiga dari penelitian ini adalah mengungkapkan adanya perbedaan rata-rata hasil belajar ranah pengetahuan pemrograman dasar karena pengaruh penerapan model PBL berbantuan emodul dibandingkan bahan ajar cetak pada kelas X jurusan TKJ SMK Negeri 7 Malang. Uji hipotesis pada penelitian ini yaitu melihat apakah terdapat perbe-daan hasil belajar pada ranah kognitif antara kelas berbantuan e-modul dan kelas berbantuan bahan ajar cetak. Uji hipotesis menggunakan t-test dengan Independent Sample t-test menunjukkan bahwa terdapat perbedaan hasil belajar dalam ranah pengetahuan dengan penerapan model PBL berbantuan e-modul dan berbantuan bahan ajar cetak.

Melihat dari rata-rata hasil belajar siswa ranah pengetahuan, pada kelas emodul lebih tinggi dari kelas bahan ajar cetak. Selain itu penerapan model pembelajaran yang sesuai dapat mendukung tingkat hasil belajar pada materi pembelajaran penggunaan array untuk menyimpan data di memori. Materi pembelajaran penggunaan array menuntut siswa untuk 
dapat menyusun sistematika penyelesaian masalah, karena itu model pembelajaran PBL dirasa cocok digunakan pada mata pelajaran tersebut. Dengan adanya penggunaan model pembelajaran PBL pada proses pembelajaran, maka terlihat bahwa terdapat pengaruh perbedaan hasil belajar ranah pengetahuan dari penggunaan bahan ajar yang berbeda. Pada hasil belajar ranah pengetahuan terlihat bahwa hasil belajar pada kelas e-modul lebih tinggi dibandingkan kelas bahan ajar cetak. Jadi ketika dilakukan uji hipotesis untuk melihat perbedaan hasil belajar ranah pengetahuan dari kedua kelas terlihat bahwa terdapat perbedaan yang signifikan dari kelas e-modul dengan kelas bahan ajar cetak.

\section{SIMPULAN DAN SARAN}

Setelah melakukan penelitian, perhitungan data dan pengujian hipotesis, peneliti memperoleh kesimpulan sebagai berikut. Berdasarkan deskripsi data nilai hasil belajar ranah kognitif dari kelas emodul, terlihat bahwa terdapat peningkatan hasil belajar yang dipengaruhi oleh model pembelajaran PBL dengan menggunakan bahan ajar e-modul. Hal ini dapat dilihat dari peningkatan perolehan rata-rata hasil belajar ranah kognitif dari sebelum dilakukan eksperimen dengan setelah dilakukan eksperimen. Rata-rata hasil belajar ranah kognitif sebelum dilakukan eksperimen berada dibawah nilai KKM, sedangkan setelah dilakukan eksperimen berada jauh di atas nilai KKM.

Berdasarkan deskripsi data nilai hasil belajar ranah kognitif dari kelas bahan ajar cetak, terlihat bahwa terdapat peningkatan hasil belajar yang dipengaruhi oleh model pembelajaran PBL dengan menggunakan bahan ajar cetak. Hal ini dapat dilihat dari peningkatan perolehan rata-rata hasil belajar ranah kognitif dari sebelum dilakukan eksperimen dengan setelah dilakukan eksperimen. Rata-rata hasil belajar ranah kognitif sebelum dilakukan eksperimen berada dibawah nilai KKM, sedangkan setelah dilakukan eksperimen berada sejajar dengan nilai KKM.

Berdasarkan data nilai rata-rata hasil belajar ranah kognitif yang didapatkan, dapat disimpulkan bahwa penerapan model PBL berbantuan e-modul lebih dapat meningkatkan kognitif siswa dibandingkan penerapan modul PBL berbantu bahan ajar cetak dikarenakan media ini membantu siswa untuk melakukan pemecahan masalah dengan menggunakan statement pemrograman yang diajarkan.

Berdasarkan pembahasan dan kesimpulan yang telah dikemukakan, maka peneliti menyarankan hal-hal berikut: (1) bagi guru pemrograman dasar. Bagi guru yang ingin menerapkan model PBL hendaknya mampu mengelola proses belajar mengajar dan mengatur waktu dengan baik supaya sintaks dari model pembelajaran ini dapat berjalan dengan baik dan efisien. Sementara itu guru juga dapat menerapkan model PBL menggunakan bahan ajar e-modul, sehingga dapat mempermudah pencapaian tujuan instruksional dan dapat meningkatkan hasil belajar siswa, khususnya pada mata pelajaran pemrograman dasar; (2) bagi siswa. Penggunaan dan penerapan bahan ajar berbantuan disini dapat bermanfaat untuk pembelajaran yang selanjutnya, dikarenakan dengan penggunaan bahan ajar berbantuan ini memberikan banyak dampak positif bagi siswa dalam proses pembelajaran; (3) bagi sekolah. Penggunaan dan penerapan bahan ajar berbantuan disini dapat digunakan untuk melihat dan melakukan evaluasi ketika proses pembelajaran. Penggunaan bahan ajar yang lebih modern akan dapat mendorong motivasi dan ketertarikan siswa terhadap materi pembelajaran yang diberikan; dan (4) peneliti selanjutnya. Perlu adanya penelitian lebih lanjut terhadap beberapa faktor yang mempengaruhi hasil belajar 
dengan menggunakan bahan ajar berbantuan e-modul dan dengan berbantuan bahan ajar cetak. Perlu dilakukan penelitian dengan menggunakan model pembelajaran yang berbeda selain dengan PBL dan dengan penggunaan bahan ajar berbantuan yang lainnya pula. Hal ini dilakukan agar dapat mengetahui seberapa baik bahan ajar yang digunakan dalam proses pembelajaran untuk dapat menunjang hasil belajar siswa. Pada penelitian selanjutnya juga diharapkan dapat mengembangkan bahan ajar yang bermanfaat bagi sekolah, agar nantinya dapat menunjang mutu pendidikan. Kemudian untuk kesempurnaan penelitian ini, disarankan mengadakan penelitian lanjutan dengan melibatkan variabel-variabel afektif lainnya, seperti gaya belajar, berpikir kritis, pemahaman konsep, maupun variabelvariabel afektif lainnya.

\section{DAFTAR RUJUKAN}

Arikunto, S. 2010. Prosedur Penelitian Suatu Pendekatan Praktik. Jakarta: Rineka Cipta.

Daryanto. 2013. Menyusun Modul Bahan Ajar untuk Persiapan Guru Dalam Mengajar. Yogyakarta: Gava Media.

Hosnan, M. 2014. Pendekatan Saintifik dan Konstektual dalam Pembelajaran Abad 21. Jakarta: Ghalia Indonesia.

Rachmawanto, E.D.E., Putro, S.C., \& Pujianto, U. 2015. Perbandingan Kemandirian Belajar Teknik Animasi 2D Pada Penerapan Tiga Model Pembelajaran Terhadap Siswa SMK. Jurnal Pendidikan Sains: Vol. 3, No.2. (Online). (http://journal.um.ac. id/index.php/jps/), diunduh November 2017.
Ramadhan, M.I., Aeni, A.N., \& Sujana, A. 2016. Penerapan Model PBL Berbantuan Multimedia untuk Meningkatkan Hasil Belajar Siswa Pada Materi Daur Air dan Peristiwa Alam. Jurnal Pena Ilmiah: Vol.1, No.1. (Online). (http://ejournal. upi.edu/) diunduh 29 Oktober 2017.

Rijal, B.S. 2014. Pengembangan Modul Elektronik Perakitan dan Instalasi Komputer Sebagai Sumber Belajar Untuk Kelas X SMK PIRI 1 YOGYAKARTA. Skripsi diterbitkan: (http://eprints.uny.ac.id/), diunduh Oktober 2017.

Rusdiharti, A.D.P. 2017. Perbedaan Rata-Rata Hasil Belajar dan Kemandirian Belajar Pemrograman Web Karena Penerapan Model PjBL Berbantuan Digi Book Dibandingkan Dengan Berbantuan Reference Book Pada Siswa Kelas X Program Keahlian RPL di SMKN 2 Singosari. Skripsi tidak diterbitkan. Malang: FT UM.

Rusman. 2010. Model-model Pembelajaran: Mengembangkan Profesionalisme Guru. Bandung: Raja Grafindo Persada.

Susanto, A. 2013. Teori Belajar dan Pembelajaran di Sekolah Dasar. Jakarta: Kecana Prenada Media Group. Warsono \& Hariyanto. 2012. Pembelajaran Aktif Teori dan Asesment. Bandung: Remaja Rosda Karya 